\title{
COMPARISON OF DIFFERENT METHODS TO MEASURE SOIL EROSION IN THE CENTRAL EBRO VALLEY
}

\author{
J. LEÓN ${ }^{1 *}$ D. BADÍA ${ }^{2}$, M.T. ECHEVERRÍA ${ }^{1}$
}

\begin{abstract}
${ }^{1}$ Department of Geography and Land Management, Zaragoza University, Spain. ${ }^{2}$ Department of Agricultural Science and Environment, Zaragoza University, Huesca, Spain.
\end{abstract}

\begin{abstract}
Fire is a natural factor of landscape evolution in Mediterranean ecosystems. Due to social and economical changes, wildfires have caused hydrological and geomorphological changes to be more pronounced, resulting in enhanced soil erosion. The study area is located in the Zuera Mountains, near the city of Zaragoza (Spain) in the Middle Ebro Valley. These mountains were affected by two wildfires in 2008 and 2009, burned around 2000 ha and 6000 ha, respectively. Middle Ebro Valley has extreme aridity, which results in a low plant cover and high soil erodibility enhanced by the fire effects. Soil infiltration is one of the properties affected by fire as a consequence of litter and vegetation removal, heating of and changes to the biological, chemical and physical soil properties. The objective was to compare two different methods -rainfall simulations and erosion plots-, to assess soil erosion after forest fires. We compared different measurements with rainfall simulators and erosion plots, applying a woodchip cover -in order to reduce the rain splash effect-, and to measure the erosion reduction. The work showed low sediment rates in both experiments covered with woodchips.
\end{abstract}

\section{Comparación de diferentes métodos para medir la erosión del suelo en el sector central del valle del Ebro}

RESUMEN. El fuego es un factor natural de la evolución paisajística de los ecosistemas Mediterráneos. Debido a los cambios sociales y económicos, los incendios forestales han causado cambios hidrológicos y geomorfológicos aún más pronunciados, provocando una mayor erosión del suelo. El área de estudio se localiza en las Montañas de Zuera, cerca de la ciudad de Zaragoza (España), en el sector central de la Depresión del Ebro. Estas montañas fueron afectadas por dos incendios en 2008 y 2009, quemándose en torno a 2000 ha y 6000 ha, respectivamente. El sector central del Valle del Ebro tiene una aridez extrema, lo que se traduce en una cubierta vegetal baja y alta erosionabilidad del suelo y ésta se ve reforzada por los efectos del fuego. La infiltración del suelo es una de las propiedades afectadas por el fuego como consecuencia de la eliminación de la vegetación y la hojarasca, por el aumento 
de temperatura y los cambios en las propiedades físicas, químicas y biológicas del suelo. Nuestro objetivo fue comparar dos métodos diferentes-simulaciones de lluvia y parcelas de erosión-, para evaluar la erosión del suelo tras incendios forestales. Se compararon diferentes mediciones con un simulador de lluvia y con parcelas de erosión, aplicando una cubierta de astillas -con el fin de reducir el efecto de la salpicadura de las gotas de lluvia-. El trabajo muestra bajas tasas de sedimentos en ambos experimentos cubiertos con astillas de madera.

Key words: erosion plots, forest fire, infiltration, runoff, rainfall simulator, sediment yield, wood-chips mulch.

Palabras clave: parcelas de erosión, incendios forestales, infiltración, escorrentía, simulador de lluvia, producción de sedimentos, acolchado de astillas.

Received 12 January 2015

Accepted 17 March 2015

* Corresponding author: Department of Geography and Land Management, Zaragoza University, Spain. E-mail: fcojleon@unizar.es

\section{Introduction}

Fire is a natural factor of landscape evolution in Mediterranean ecosystems. Forest fires destroy the vegetation cover, alter the soil properties and trigger higher erosion rates by splash erosion that can contribute to modify the laminar flow and to rejuvenate the gullies (Hyde et al., 2007). The important socio-economic changes that occurred in the last decades have contributed to an increase in forest fires (Shakesby, 2011), altering the fire regimes in terms of frequency, size, seasonality and recurrence as well as fire intensity and severity (Doerr and Cerdà, 2005; Keeley, 2009) causing severe effects on soils, water and vegetation (Bento-Gonçalves et al., 2012; Guénon et al., 2013).

Research on soil erosion following fires in the Mediterranean basin has a brief history. Publications date back only to the early 1960s (SanRoque and Rubio, 1982; Díaz-Fierros et al., 1987) compared with research on fires in the USA, where investigations began in the 1930s (Connaughton, 1935). The research activity in the Mediterranean basin expanded and has been increasingly internationally oriented since the 1990s, when there was an exponential risk of fire activity (Moreno et al., 1998; Pausas, 2004) and an average of 600000 ha burned annually, linked to 50000 fires in the late last century (Lloret and Zedler, 2009).

Fire affects soil properties directly by heat impact and ash incorporation and reduction or elimination of plant cover (Bodí et al., 2014). Raindrop impact on burnt soils can lead to the structural degradation of the soil surface (Bresson and Boiffin, 1990; Poesen and Nearing, 1993; Ramos et al., 2003). Aggregate breakdown liberates small soil particles forming a surface crust with low permeability to air and water (Llovet et al., 2008; Mataix Solera et al., 2011, León et al., 2013). Besides, ash plays an important role in soil protection after the forest fire and after the first storms and winds (Cerdà and Doerr, 2008; León et al., 2013a,b; Pereira et al., 2013). These are the reasons why research on the effect of restoration measures 
in burnt areas started since the second half of the 20th century (Gross et al. 1989; Miles et al. 1989; Cerdà and Robichaud 2009). These measures include apply different types of covers or mulch (straw, wood-chip or shredded mulching, straw pellets, pine straws) or sowing and building barriers in order to reduce erosion and runoff (Bautista et al. 1996; Badía and Martí 2000; Wagenbrenner et al. 2006; Cerdà and Doerr 2008; Groen and Woods 2008; Fernández et al. 2011; León et al., 2012).

Soil erosion by water is an extremely active process in soils affected by forest fires and decisive for the evolution of burned areas because it eliminates the layer of ash and the organic horizon, the most abundant nutrient reservoir. The recovery of the soil, vegetation and water quality all depend on the post-fire erosion processes. Thus, the details regarding post-fire erosion are critical for elucidating the magnitude of the impact of fire on soils (Mataix-Solera and Cerdà, 2009). The first experimental studies on soil erosion after fires used an estimation method based on Universal Soil Loss equation (USLE: Wischmeier and Smith, 1965; Rubio, 1987; Díaz-Fierros et al., 1987). Another method uses erosion plots in which specific areas of a slope are delineated to measure runoff and the amount of sediment exported for the calculation of erosion rates. This method was used to contribute data that were necessary to understanding the effect of fire on soil erosion in Spain (Vega and Díaz-Fierros, 1987; Soler and Sala, 1990; Sánchez et al., 1994; Úbeda and Sala, 1998; Badía and Martí, 2000; Pardini et al., 2004).

The study of soil erosion after forest fires has followed two strategies: monitoring plots for years to compare control and burned plots (paired) or taking plot measurements to determine the evolution of soil loss until the erosion rates recover to levels typical of pre-fire forest soils (Shakesby, 2011; Bento-Gonçalves et al., 2012; Malvar et al., 2015). There are methodological problems with both strategies because of the spatial and temporal variability in rainfall. Rainfall simulators have helped to overcome these problems and understand why, under identical rainfall conditions, soils affected by fire erode at higher rates than those unaffected by fire (Calvo and Cerdà, 1994; Llovet et al., 1994; Badía and Moreu, 1996; Cerdà, 1998; Badía and Martí, 2008; León et al., 2013a).

In general, an increase in the erosion rate has been quantified after fire (Soler and Sala, 1990; Mayor et al., 2007). However, certain studies have noted contrasting behavior by burned soil in studies with high prefire variability in soil loss and rainfall between the burned and the reference or control plots (Cerdà and Lasanta, 2005). In addition to the high spatial and temporal variability of soil loss in Mediterranean ecosystems because of erratic rains, the following factors may also influence these contrasting behaviors of burned areas: the soil rockiness (Cerdà and Navarro, 1997a,b; Rubio et al., 1997); fire intensity and severity (Neary et al., 1999; Shakesby, 2011), and their recurrence (Gimeno et al., 2000); the postfire management, particularly as affected by ploughing (Edeso et al., 1998; Malvar et al., 2011, 2013); and the measures taken to control the subsequent erosion (Bautista et al., 1996), such as the application of straw mulch (Fernández and Vega, 2014; Robichaud et al., 2014), seeding or mulching (Badía and Martí, 2000; Vega et al., 2015) or other applications for soil conservation and erosion control (Abad et al., 2000).

Measurements taken over intervals of 30 years have led to the conclusion that although erosion rates increase after fires, these rates return to their previous values after a few years 
(Cerdà and Lasanta, 2005; Mayor et al., 2007). Mediterranean erosion processes are governed by extreme events (González-Pelayo et al., 2010). However, the increasing recurrence of fires due to climatic and anthropogenic factors causes higher erosion rates that may trigger land degradation processes (Mataix-Solera and Cerdà, 2009).

Soil infiltration is one of the properties affected by fire as a consequence of litter and vegetation removal, and heating of and changes to the biological, chemical and physical soil properties. Rainfall simulations are a remarkably useful tool to assess changes on soil properties and erosion by raindrop impact, especially in semiarid areas, where precipitation regime is irregular, having intense and short-duration events (Seeger, 2007; Cerdà et al., 2009; León et al., 2012). It is an essential tool for investigating the different erosion processes in the field and in the laboratory, quantifying rates of infiltration, runoff and sediment (Cerdà et al., 2010; Iserloh et al., 2013a). A rainfall simulator allows a fast and replicated assessment of the meaning and impact of several factors, such as slope, soil type, soil moisture, soil structure, aggregate stability, vegetation cover and vegetation structure (Schmidt, 1998). The small portable rainfall simulator (plot size below $5 \mathrm{~m}^{2}$ ) have become more widely used in current research (Cerdà et al., 2010; Nadal-Romero et al., 2011; León et al., 2012; Iserloh et al., 2013a) because it has many advantages such as low cost, easy handling, easy transport areas, low water consumption and high replication rates of measurements (Iserloh et al., 2013a). However, in contrast, it presents some disadvantages such as the lack of standardization in design, rainfall intensities, rain spectra and drop size and distribution, which impede drawing a meaningful comparison between results. The Thies Laser Precipitation Monitor, which represents the most up-todate and accurate measurement technique for obtaining information on drop-spectra and drop fall velocity was used (Iserloh et al., 2013a). The quantity and spatial distribution of the simulated rain can be easily monitored with rain gauges.

The aim of this work was to compare i) the sediment yield with two different measurements -with a rainfall simulator and erosion plots- and ii) to compare the sediment yield with two different treatments -with and without wood chips.

\section{Material and methods}

\subsection{Study area}

The Zuera Mountains, located north of the city of Zaragoza (NE-Spain), have suffered more than 40 fires during the period 1920-2006 (Villar, 2006). The mountain vegetation has a good natural recovery, especially in north-facing slopes. However, the long anthropogenic influence, the semiarid climate and shallow soils have been very harmful with respect to the effects and recurrence of fire, particularly those burning in degraded areas. The last large fires were in 2008 (2 000 ha) and 2009 (more than 6000 ha). This study was carried out in Castejón (UTM 30T, X671106, Y4644584) under an Aleppo pine forest that burned in 2008, and in Remolinos (UTM 30T, X656794, Y4639884) under shrubland that burned in 2009 (Fig. 1).

The vegetation at Castejón is characterized by a mixed forest (Pinus halepensis Mill. and Quercus coccifera L.) and scrubs (Brachypodium phoenicoides L., Brachypodium retusum 
Pers., Juniperus oxycedrus L., Lonicera etrusca G., Genista scorpius L., Helianthemun marifolium Mill., Osyris alba L., Pistacea lentiscus L., Rhamnus lyciodes L. subsp. lyciodes, Rosmarinus officinalis L), whereas in the Remolinos area, the scrub formation is dominant (Genista scorpius L., Retama sphaerocarpa L., Rosmarinus officinalis L., Gypsophila struthium Willk subsp. Hispanica, Ononis tridentata L., and Quercus coccifera L.) and Pinus halepensis Mill. The climate is the same in both areas. It is Mediterranean continental, with a mean annual rainfall up to $450 \mathrm{~mm}$ and a temperature variation from $-7.1^{\circ} \mathrm{C}$ to $36.5^{\circ} \mathrm{C}$. The mean annual reference evapotranspiration is approximately $1406 \mathrm{~mm}$ (using FAO56 by Penman Monteith method) and is enhanced by strong winds, which cause the water deficit to be one of the highest in Europe (Herrero and Synder, 1997). The geomorphological units (between 200 and $748 \mathrm{~m}$ a.s.l.) are platforms on carbonate and evaporitic tertiary formations and flat bottom valleys. The soils on limestone parent material are Rendzic Phaeozem with a clay loam textural class on Ah horizons (Badía et al., 2013) in both areas.

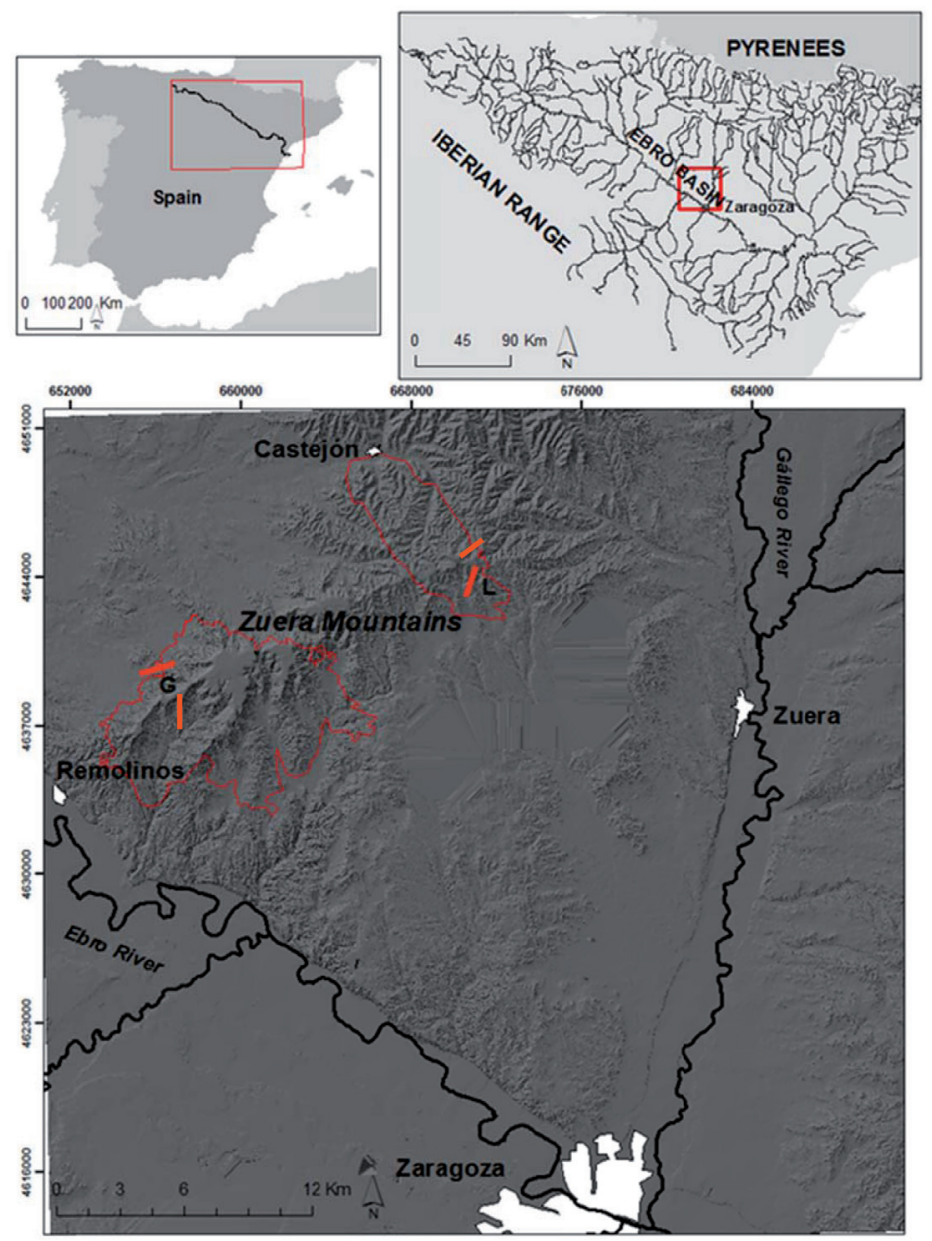

Figure 1. Study area: Remolinos fire in 2009 (G) and Castejón fire in 2008 (L). 


\subsection{Rainfall simulation}

The rainfall simulator was previously described by Cerdà et al. (1997) and Lasanta et al. (2000), with four metallic legs, a plastic cover to protect the trial from the wind, a cone spray nozzle (Lechler 460.688) and a $0.7 \mathrm{kw}$ motorized pump (Garland GTP25). The rain simulator was gauged with a Laser Disdrometer (Thies)-detailed in Fister et al. (2011): raindrop distribution of $97.8 \%$ of the Christiansen Coefficient, rain intensity of $52.5 \mathrm{~mm} \mathrm{~h}^{-1}$, average drop size of $0.5 \bullet 1 \mathrm{~mm}$ (D50) and kinetic energy around 4.16 $\mathrm{J} \mathrm{m}^{-2} \mathrm{~mm}^{-1}$ (Iserloh et al., 2013b). A circular simulation plot was used having a surface area of $0.21 \mathrm{~m}^{2}$ and rain was applied from a $2.2 \mathrm{~m}$ height (Fig. 2).

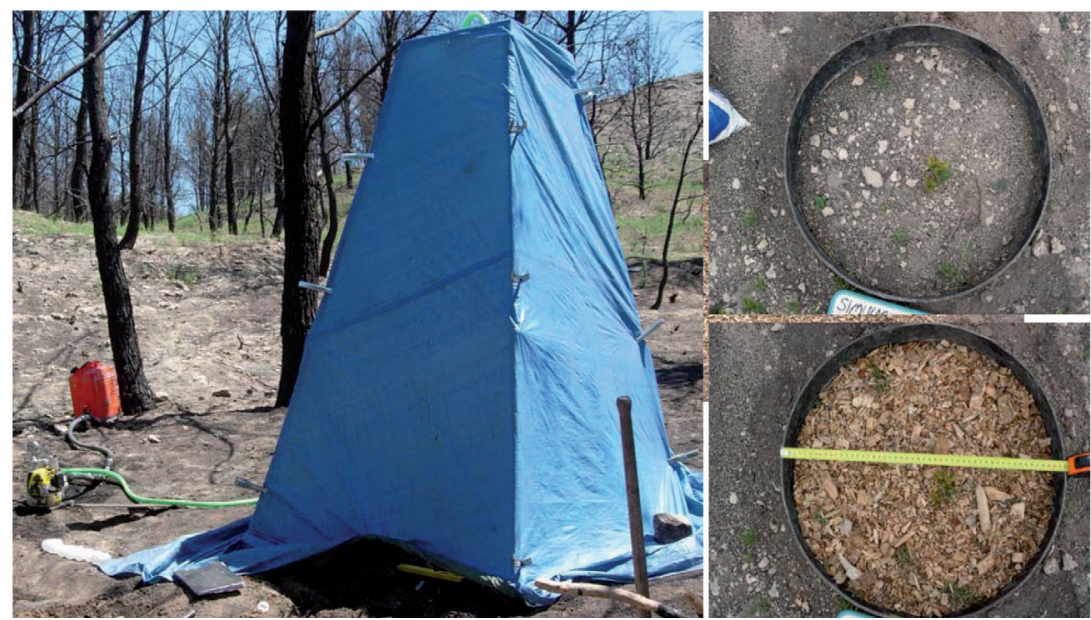

Figure 2. Rainfall simulator in Castejón fire and rainfall plots.

Rainfall simulations were used as a tool to compare the hydrogeomorphological behavior after the fire and to validate the use of wood chips as a resource to stop erosion in the area of Castejón. In total, 16 rainfall simulations were carried out (November 2008 until June 2009): 8 simulations with wood chips and 8 simulations without wood chips on burnt soils. Each of the simulations lasted 60 minutes.

Erosion plots and rainfall simulation plots were similar in terms of slope and topographic exposure -hillsides facing northeast with an inclination of around $10 \%$. Each plot was characterized according to the percentage of vegetation cover, stoniness, soil humidity, and bulk density (including the organic horizon -litter, fallen leaves or ashes). The presence of ashes having different color and thickness provided information relative to fire intensity, which was higher in pinewood areas and lower in scrub areas.

\subsection{Erosion plots}

We built 12 open erosion plots $\left(2 \mathrm{~m}^{2}\right)$ in Remolinos area with six replicates by treatment (November 2009 until June 2010): 6 burnt and 6 burnt with wood-chips, with a meter separation between plots to avoid overlap (Fig. 3). The experiment finished due to external problems. 
The sediment washed away by runoff was collected in a "Gerlach" or sediment trap at the lower end of each of the plots $(1 \mathrm{~m})$. We collected, identified and analysed in laboratory the sediment after rainfall events.

\subsection{Application of wood chips}

In order to test the mulching effect, wood chips from the burnt pine trees were used in situ (Pinus halepensis Mill.), covering $100 \%$ of the plot with $2.85 \mathrm{~kg} \mathrm{~m}^{-2}$ of chips having different size and thickness -between 0.5 and $2 \mathrm{~cm}$ (Fig. 2). By applying wood-chip mulching we can study the effects on erosion after the fire, as wood-chips are very easy to obtain due to the high availability of dead wood after a fire. Wood chips reduce the rain impact, loss of soil by rain splash and the effects of runoff and runoff geomorphological effects. We measured the vegetation cover and the stone cover in the soils before to apply the mulching. We chose wood chips instead of straw because this area is faced mainly northwest, where there is a strong and predominant wind with mean monthly wind speeds around $20 \mathrm{~km} \mathrm{~h}^{-1}$, which removes the straw mulch.
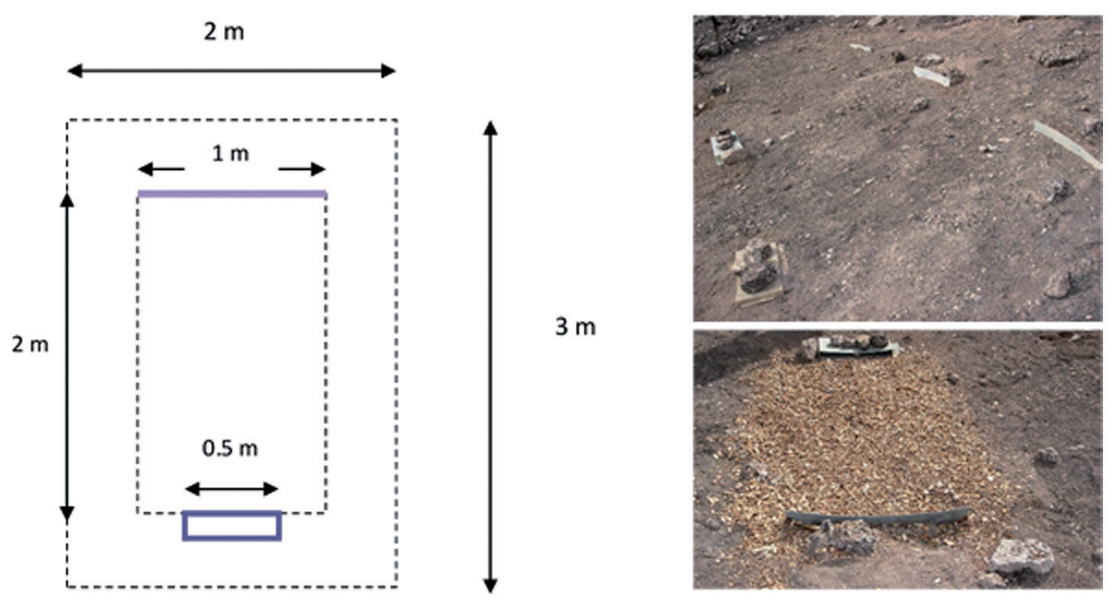

Figure 3. Erosion plots in Remolinos fire.

\section{Results}

\subsection{Rainfall simulation}

The results obtained from the rainfall simulations indicate that average runoff rates are much higher on burnt soils $\left(9.39 \pm 5.81 \mathrm{~mm} \mathrm{~h}^{-1}\right)$ than on burnt soils covered with wood-chips $\left(4.36 \pm 3.85 \mathrm{~mm} \mathrm{~h}^{-1}\right)$. Wood-chip applications reduce erosion as a result of the protective effect of wood chips, such that the sediment yield was $3.82 \pm 2.90 \mathrm{~g} \mathrm{~m}^{-2}$ in the case of burnt soils and $1.91 \pm 2.43 \mathrm{~g} \mathrm{~m}^{-2}$ in the case of burnt soils covered with wood-chips (Table 1 and Fig. 4). Using woodchips acidifies runoff water; however it does not significantly affect the electric conductivity (EC) or the organic matter content (OM) of runoff water (Table 1). 
Table 1. Mean value and standard deviation during rainfall simulations.

\begin{tabular}{|c|c|c|}
\hline & \multicolumn{2}{|c|}{ Calcareous soils } \\
\hline & Burnt & Burnt + wood-chips \\
\hline Slope (\%) & $9.62 \pm 1.78$ & $13.57 \pm 4.71$ \\
\hline Vegetation cover $(\%)$ & $2.50 \pm 4.18$ & $6.89 \pm 14.57$ \\
\hline Stone cover $(\%)$ & $34.00 \pm 24.31$ & $25.83 \pm 13.99$ \\
\hline Soil moisture (\%) & $14.00 \pm 11.39$ & $6.70 \pm 3.48$ \\
\hline Bulk density $\left(\mathrm{g} \mathrm{l}^{-1}\right)$ & $0.73 \pm 0.05$ & $0.67 \pm 0.03$ \\
\hline Ponding time (min) & $5.24 \pm 2.35$ & $5.03 \pm 2.69$ \\
\hline Runoff $\left(\mathbf{m m ~ h}^{-1}\right)$ & $9.39 \pm 5.81$ & $4.36 \pm 3.85$ \\
\hline Runoff reduction (\%) & \multicolumn{2}{|c|}{46.43} \\
\hline Sediment $\left(\mathrm{g} \mathrm{m}^{-2}\right)$ & $3.82 \pm 2.90$ & $1.91 \pm 2.43$ \\
\hline Soil erosion reduction $(\%)$ & \multicolumn{2}{|c|}{50.00} \\
\hline pH & $7.44 \pm 0.38$ & $7.03 \pm 0.03$ \\
\hline $\mathrm{EC}\left(\mu \mathrm{S} \mathrm{cm} \mathrm{cm}^{-1}\right)$ & $996.82 \pm 469.38$ & $610.83 \pm 82.07$ \\
\hline $\mathrm{OM}\left(\mathrm{mg} \mathrm{l}^{-1}\right)$ & $0.07 \pm 0.06$ & $0.12 \pm 0.16$ \\
\hline
\end{tabular}

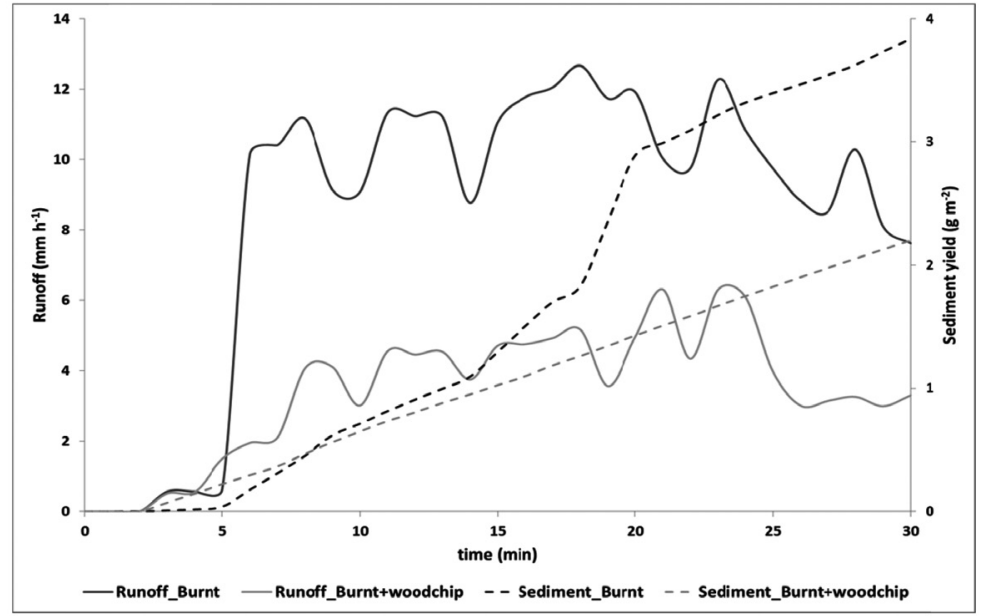

Figure 4. Runoff and sediment yield with a rainfall simulator.

\subsection{Erosion plots}

In the case of the soil erosion plots, the application of mulch with wood-chip reduces the sediment yield (Table 2$)$ in the burnt soils $\left(20.01 \pm 18.70 \mathrm{~g} \mathrm{~m}^{-2}\right)$ compared with burnt soils without wood-chips $\left(25.70 \pm 20.96 \mathrm{~g} \mathrm{~m}^{-2}\right)$. From the first rain the application of mulch woodchips reduced soil loss (Fig. 5). The percentage of bare soil at the time of trial stood was at $80 \%$ on average, and reduced to less than $3 \%$ with the application of mulch wood-chips. However, this percentage dropped sharply because of the northwest wind in the next months, which led to a progressive standardization of results between treatments. 


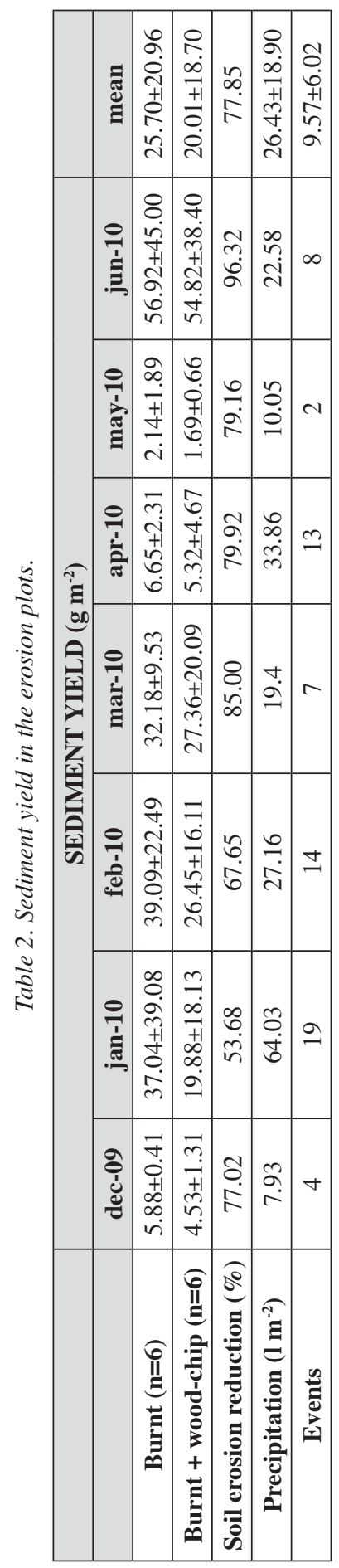




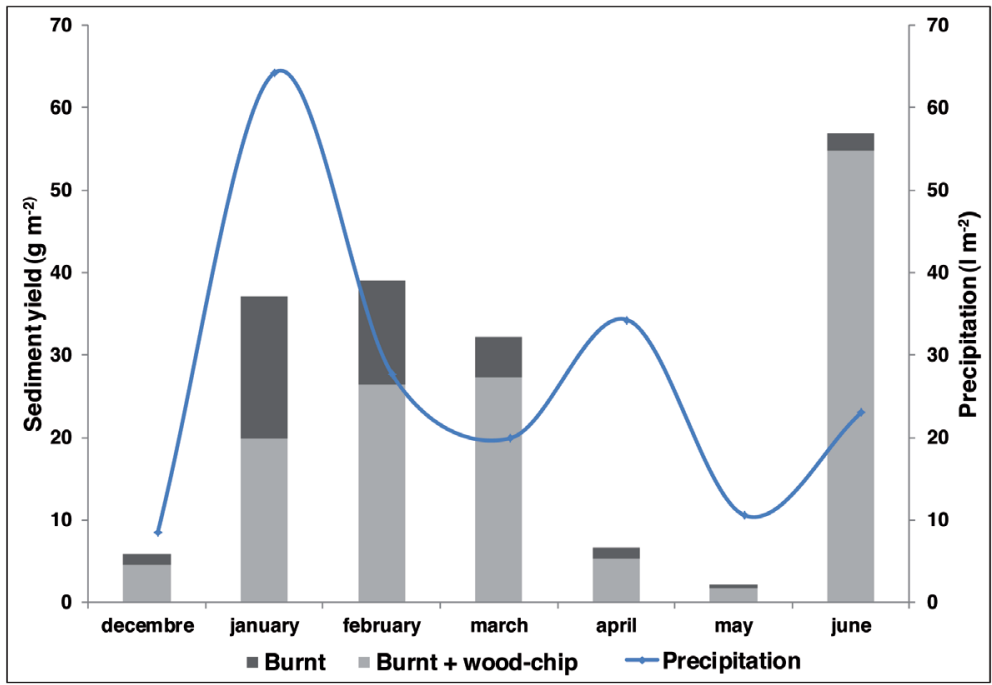

Figure 5. Sediment yield in the erosion plots (period 2009-2010).

\section{Discussion}

As shown by another research conducted in the central sector of the Ebro Depression (Badía and Martí 2000), where different mulch techniques where applied on burnt areas, they are efficient to reduce the sediment yield in soils affected by wildfires.

Introducing wood-chips means reducing erosion. Firstly, a decrease of $50 \%$ for calcareous soils was observed as a consequence of runoff reduction. Runoff reduction is also observed in other studies where different mulch types are applied, such as straw or wood chips (e.g. Bautista et al. 1996; Badía and Martí 2000; Wagenbrenner et al. 2006; Groen and Woods 2008; Cerdà and Robichaud 2009; Fernández et al. 2011). Nevertheless, mulching allows the production of runoff, but the amount of sediment decreased, compared to the bare soil situation: a decrease of $22 \%$ in the case of both areas. Badía and Martí (2000) observed similar values (37\%) in soils affected by forest fires in calcareous soils. Bautista et al. (1996) and Wagenbrenner et al. (2006) indicate reductions of 95 and $91 \%$ with straw mulching compared to untreated soils. In these studies mulch was applied to cover between 70 and $100 \%$ of the plot. Robichaud et al. (2000) suggests that for mulching to be effective at least $60 \%$ of the surface be covered. Fernández et al. (2011) used wood chips to cover $45 \%$ of the plot and straw mulch that covered $80 \%$ of the plot, but they found wood chips to be not useful. Cerdà and Doerr (2008) assessed the role of pine needles deposited on the soil after a fire, and found an erosion reduction of $10 \%$ compared to unprotected surfaces.

Foltz and Wagenbrenner (2010) demonstrated the effectiveness of wood chips with 50 and $70 \%$ cover, with a reduction in runoff and sediment concentration. Similarly, 
Bautista et al. (2009) suggested that a mixture of wood chips, pine needles and twig applied as mulch reduced erosion in a burned area in Alicante (2002), without altering the plant auto succession . However, Cerdà and Robichaud (2009) remarks that the mulch can be ineffective to reduce runoff and erosion if rainfalls are intense. Other authors showed how the straw mulch applied in Southern California after a fire in late 2003 was removed by strong winds (Bautista et al., 2009; Foltz and Wagenbrenner, 2010). For Robichaud et al. (2014) unlike seeding, straw mulch has been found to be quite effective in reducing post-fire erosion, which has led to the development and use of other mulches, such as hydromulch and wood strands, for post-fire stabilisation. For Prats et al. (2013) hydromulching was highly effective during the first 19 months after its application, reducing total runoff volumes by $70 \%$ and total soil losses by $83 \%$, and continued effectively during the third year following the wildfire. And for Vega et al. (2015) mulching with seeding was clearly much more efficient that seeding alone in terms of minimizing soil erosion.

Finally Foltz and Wagenbrenner (2010) suggest that we must not forget, when applying different types of mulching on a large scale, the cost-effective, ecologically sustainable and environmentally benign, widely available and easily transported, and durable and stable enough to provide protection until natural ground cover has been reestablished.

\section{Conclusions}

Both methods -rainfall simulation and erosion plots- are useful to assess soil erosion. The application of wood chip mulch after a wildfire in both methods, reduces runoff rates by half, and soil erosion in $22 \%$. Therefore, post-fire mulching is very effective for reducing runoff but showed a limited effectiveness in reducing soil erosion.

The application of mulching with wood chips is expensive, such that it is only efficient if the wood of dead vegetation can be used. We suggest that some factors such as the vegetation recovery capacity, the soil type, the slope distribution and the fire severity must be considered before selecting the material to apply. The results form this research can help the land managers to select the most appropriate material.

\section{Acknowledgements}

This research was supported by the Ministry of Science and Innovation BES2008-003056, the CETSUS project (CGL2007-66644-C04-04/HIDCLI), and the Geomorphology and Global Change Research Group (D.G.A., 2011). The Spanish Army supported this work at the San Gregorio CENAF.

\section{References}

Abad, N., Bautista, S., Blade, C., Caturla, R.N. 2000. Seeding and mulching as erosion control techniques after wildfires in the Valencia region. In Mediterranean Desertification Research 
Results and Policy Implications, P. Balabanis, D. Peter, A. Ghazi, M. Tsogas (Eds.), Directorate-General Research vol. 2, European Commission, Brussels, pp. 419-429.

Badía, D., Martí, C. 2000. Seeding and mulching treatments as conservation measures of two burned soils in the Central Ebro Valley, NE Spain. Arid Soil Research nd Rehabilitation 13, 219-232.

Badía, D., Martí, C., Aznar, J.M., León, J. 2013. Influence of slope and parent rock on soil genesis and classification in semiarid mountainous environments. Geoderma 193-194, 13-21.

Bautista, S., Bellot, J., Vallejo, V.R. 1996. Mulching treatment for postfire soil conservation in a semiarid ecosystem. Arid Land Research and Management 10, 235-242.

Bautista, S., Robichaud, P.R., Bladé, C. 2009. Post-fire mulching. In Fire effects on soils and restoration strategies, A. Cerdà, P.R. Robichaud (Eds.), Science Publishers, USA, pp. 351372

Bento-Gonçalves, A., Vieira, A., Úbeda, X., Martin, D. 2012. Fire and soils: key concepts and recent avances. Geoderma 191, 3-13. doi:10.1016/j.geoderma.2012.01.004.

Beyers, J.W., Christensen, P. Wohlgemuth, P, Gubert, K. 2006. Effects of postfire mulch treatments on vegetation recovery in the southwestern US. Proceedings Annual Meeting of the ESA, Washington.

Bodí, M.B., Doerr, S.H., Cerdà, A., Mataix-Solera, J. 2012. Hydrological effects of a layer of vegetation ash on underlying wettable and water repellent soil. Geoderma 191, 14-23.

Bodí, M.B., Martín, D.A., Balfour, V.N., Santín, C., Doerr, S.H., Pereira, P., Cerdà, A., MataixSolera, J. 2014. Wildland fire ash: Production, composition and eco-hydro-geomorphic effects. Earth-Science Review 130, 103-127.

Bresson, L.M., Boiffin, J. 1990. Morphological characterization of soil crust development stages on an experimental field. Geoderma 47, 301-325.

Calvo, A., Cerdà, A. 1994. An example of the changes in the hydrological and erosional response of soil after a forest fire, Pedralba (Valencia), Spain. In Soil Erosion as a consequence of forest fires, A. Calvo (Ed.), Geoforma Ediciones, Logroño, pp. 99-110.

Cerdà, A., Navarro, R. 1997a. Tasas de erosión en una solana de la Serra Grossa: La costera. Cuadernos de Geografía 59, 27-46.

Cerdà, A., Navarro, R. 1997b. Procesos de erosión en los badlands alicantinos. Investigaciones Geográficas 17, 99-116.

Cerdà, A., Lasanta, T. 2005. Long-term erosional responses after fire in the Central Spanish Pyrenees: 1. Water and sediment yield. Catena 60, 59-80.

Cerdà, A., Doerr, S.H. 2008. The effect of ash and needle cover on surface runoff and erosion in the immediate post-fire period. Catena 74, 256- 263. doi:10.1016/S0341-8162(02)00027-9.

Cerdà, A., Robichaud, P. R. 2009. Fire effects on soils and restoration strategies. Land Reconstruction and Management, Vol. 5, Oxford, pp. 41-295.

Cerdà, A., Ibáñez, S., Calvo, A. 1997. Design and operation of a small and portable rainfall simulator for rugged terrain. Soil Technology 11, 163-170.

Cerdà, A. Giménez-Morera, A., Bodí, M.B. 2009. Soil and water losses from new citrus orchards growing on sloped soils in the western Mediterranean basin. Earth Surface Processes and Landforms 34 (13), 1822-1830. DOI: 10.1002/esp.1889.

Cerdà, A., Marcos, E., Llovet, J., Benito, E., Pérez-Cabello, F., Úbeda, X., Jordán, A., Zavala, L.M., Ruiz-Sinoga, D. 2010. La lluvia simulada como herramienta para la investigación del efecto de los incendios forestales sobre los suelos. In Actualización de métodos y técnicas para el estudio de los suelos afectados por incendios forestales, A. Cerdà, A. Jordán (Eds.), Ed. Càtedra de Divulgació de la Ciència, Universitat de València, pp. 45-83.

Connaughton, C.A. 1935. Forest fire and accelerated erosion. Journal of Forestry 33, 751-752. 
Díaz-Fierros V., F., Benito Rueda, E., Perez Moreira, R. 1987. Evaluation of the U.S.L.E. for the prediction of erosion in burnt forest areas in Galicia (N.W. Spain). Catena 14, 189-199.

Doerr, S.H., Cerdà, A. 2005. The influence of vegetation recovery on soil hydrology and erodibility following fire: an eleven-year investigation. International Journal of Wildland Fire 14 (4), 423-437.

Edeso, J., Merino, A., González, M., Marauri, P. 1998. Manejo de explotaciones forestales y pérdida de suelo en zonas de elevada pendiente del País Vasco. Cuaternario y Geomorfología 12, 105-116.

Fernández, C., Vega, J.A. 2014. Efficacy of bark strands and straw mulching after wildfire in NW Spain: Effects on erosion control and vegetation recovery. Ecological Engineering 63, 50-57.

Fernández, C., Vega, J.A., Gras, J.M., Jiménez, E., Fonturbel, T. 2011. Effectiveness of three post-fire treatments at reducing soil erosion in Galicia (NW Spain). International Journal of Wildland Fire 20, 104-114.

Fister, W., Iserloh, T., Ries, J. B., Schmidt, R.G. 2011. Comparison of rainfall characteristics of a small portable rainfall simulator and a portable wind and rainfall simulator. Zeitschrift für Geomorphologie 55 (3), 109-126.

Gimeno, E., Andreu, V., Rubio, J.L. 2000. Changes in organic matter, nitrogen, phosphorus and cations in soil as a result of fire and water erosion in a Mediterranean landscape. European Journal of Soil Science 51, 201-210.

Giovannini, G. 2012. Fire in agricultural and forestal ecosystems: the effects on soil. Edizioni ETS, Pisa, Italy.

González-Pelayo, O., Andreu, V., Gimeno-García, E., Campo, J., Rubio, J.L. 2010. Rainfall influence on plot-scale runoff and soil loss from repeated burning in a Mediterranean-shrub ecosystem, Valencia, Spain. Geomorphology 118 (3), 444-452.

González-Pérez, J.A., González-Vila, F.J., Almendros, G., Knicker, H. 2004. The effect of fire on soil organic matter - a review. Enviroment International 30, 855-870.

Guénon, R., Vennetier, M., Dupuy, N., Roussos, S., Pailler, A., Gros, R. 2013. Trends in recovery of Mediterranean soil chemical properties and microbial activities after infrequent and frequent wildfires. Land Degradation \& Development 24 (2), 115-128. DOI: 10.1002/ldr.1109.

Groen, A.H., Woods, S. 2008. Effectiveness of aerial seeding and straw mulch for reducing postwildfire erosion, north-western Montana, USA. International Journal of Wildland Fire 17, 559-571.

Gross, E., Steinblums, I., Ralston, C., Jubas, H. 1989. Emergency Watershed treatments on burned land in southwest Oregon. In Proceedings of the symposium on Fire and Watershed Management. General Technical Report PSW-GTR: 109-114, U.S. Department of Agriculture, Pacific Southwest Research Station, Berkeley, California, USA.

Herrero, J., Snyder, R. 1997. Aridity and irrigation in Aragón, Spain. Journal of Arid Environments 35, 535-547.

Hyde, K., Woods, S.W., Donahue, J. 2007. Predicting gully rejuvenation after wildfire using remotely sensed burn severity data. Geomorphology 86, 496-511.

Iserloh, T., Ries, J. B., Cerdà, A., Echeverría, M. T., Fister, W., Geißler, C., Kuhn, N. J., León, F.J., Peters, P., Schindewolf, M., Schmidt, J., Scholten, T., Seeger, M. 2013a. Comparative measurements with seven rainfall s simulators on uniform bare fallow land. Zeitschrift für Geomorphologie 57 (1), 11-26.

Iserloh, T., Ries, J.B., Arnáez, J., Boix-Fayos, C., Butzen, V., Cerdà, A., Echeverría, M.T., Fernández-Gálvez, J., Fister, W., Geißler, C., Gómez, J.A., Gómez-Macpherson, H., Kuhn, N.J., Lázaro, R., León, F.J., Martínez-Mena, M., Martínez-Murillo, J.F., Marzen, M., Mingorance, M.D., Ortigosa, L., Peters, P., Regüés, D., Ruiz-Sinoga, J.D., Scholten, T., 
Seeger, M., Solé-Benet, A., Wengel, R., Wirtz, S. 2013b. European small portable rainfall simulators: A comparison of rainfall characteristics. Catena 110, 100-112.

Keeley, J.E. 2009. Fire intensity, fire severity and burn severity: a brief review and suggests usage. International Journal of Wildland Fire 18, 116-126.

Lasanta, T., García-Ruiz, J.M., Pérez-Rontomé, C., Sancho-Marcén, C. 2000. Runoff and sediment yield in a semi-arid environment: the effect of land management after farmland abandonment. Catena 38, 265-278.

León, J., Seeger, M., Echeverría, M.T., Badía, D., Peters, P., 2012. The effect of the fires on gypseous soil properties: changes of the hydrology and splash resistance. Vol. 14, EGU201211179.

León, J., Echeverría, M.T., Badía, D., Martí, C., Álvarez, C. 2013a. Effectiveness of Wood chips cover at reducing erosion in two contrasted burnt soils. Zeitschrift für Geomorphologie Suppl. 57 (1), 27-37.

León, J., Bodí, M.B., Cerdà, A., Badía, D. 2013b. The contrasted response of ash to wetting: The effects of ash type, thickness and rainfall events. Geoderma 209-210, 143-152.

Llovet, J., Josa, R., Vallejo, V.R. 2008. Thermal shock and rain effects on soil surface characteristics: a laboratory approach. Catena 74, 227-234.

Lloret, F., Zedler, P.H. 2009. The effect of forest fires in vegetation. In Fire effects on Soils and Restauration Strategies, A. Cerdà, P.R. Robichaud (Coord.), Enfield, Edit. Science Publishers, pp. 257-295.

Malvar, M., Prats, S., Nunes, J., Keizer, J. 2011. Post-fire overland flow generation and interrill erosion under simulated rainfall in two eucalypt stands in north-central Portugal. Environmental Research 111, 222-236.

Malvar, M.C., Prats, S.A., Keizer, J.J. 2015. Runoff and inter-rill erosion affected by wildfire and pre-fire ploughing in eucalypt plantations of North-Central Portugal. Land Degradation Development. DOI: 10.1002/ldr.2365.

Mataix-Solera, J., Cerdà, A. 2009. Incendios forestales en España. Ecosistemas terrestres y suelos. In Efectos de los incendios forestales sobre los suelos en España: el estado de la cuestión visto por los científicos españoles, A. Cerdà, J.M. Solera (Eds.), Cátedra Divulgación de la Ciencia, Valencia, pp. 25-54.

Mataix-Solera, J., Gómez, I., Navarro-Pedreño, J., Guerrero, C., Moral, R. 2002. Soil organic matter and aggregates affected by wildfire in a Pinus halepensis forest in Mediterranean environment. International Journal of Wildland Fire 11, 107-114.

Mataix-Solera J, Cerdà A, Arcenegui V, Jordán A, Zavala LM. 2011. Fire effects on soil aggregation: A review. Earth-Science Reviews 109, 44-60.

Mayor, A., Bautista, S., Llovet, J., Bellot, J. 2007. Post-fire hydrological and erosional responses of a Mediterranean landscape: seven years of catchment-scale dynamics. Catena 71, 68-75.

Miles, S.R., Haskins, D.M., Ranken, D.W. 1989. Emergency burn rehabilitation; cost, risk and effectiveness. In Proceedings of the symposium on Fire and Watershed Management, General Technical Report PSW-109: 97-102, U.S. Department of Agriculture, Forest Service, Pacific Southwest Research Station, Berkeley, California, USA.

Moreno, J.M., Vázquez, A., Vélez, R. 1998. Recent history of forest fires in Spain. In Large forest fires, J.M. Moreno (Ed.), Backhuys, Leiden, Netherlands, pp. 159-185.

Nadal-Romero, E., Lasanta, T., Regüés, D., Lana-Renault, N., Cerdà, A. 2011. Hydrological response and sediment production under different land cover in abandoned farmland fields in a Mediterranean mountain environment. Boletín de la Asociación de Geógrafos Españoles 55, 303-323.

Neary, D.G., Klopatek, C.C., DeBano, L.F., Ffolliot, P. 1999. Fire effects on belowground sustainability: a review and synthesis. Forest Ecology Management 122, 51-71. 
Pardini, G., Gispert, M., Dunjó, G. 2004. Relative influence of wildfire on soil properties and erosion processes in different Mediterranean environments in NE Spain. Science Total Environmental 328, 237-246.

Pausas, J.G. 2004. Changes in fire and climate in the Eastern Iberian Peninsula (Mediterranean Basin). Climatic Change 63, 337-350.

Pausas, J.G., Llovet, J., Rodrigo, A., Vallejo, R. 2009. Are wildfires a disaster in the Mediterranean basin? - A review. International Journal of Wildland Fire 17, 713-723.

Pereira, P., Cerdà, A., Úbeda, X., Mataix-Solera, J., Martin, D., Jordán, A., Burguet, M. 2013. Spatial models for monitoring the spatio-temporal evolution of ashes after fire - a case study of a burnt grassland in Lithuania. Solid Earth 4, 153-165.

Poesen, J.W.A. and Nearing, M.A. (Eds.) 1993. Soil surface sealing and crusting. Catena Supplement 24, Catena Verlag, Cremlinge-Destedt, Germany.

Prats, S.A., Malvar, M.C., Simões-Vieira, D.C., MacDonald, L., Keizer, J.J. 2013. Effectiveness of hydromulching to reduce runoff and erosion in a recently burnt pine plantation in central Portugal. Land Degradation \& Development. DOI: 10.1002/ldr.2236.

Ramos, M.C., Nacci, S., Pla, I. 2003. Effects of raindrop impact and its relationship with aggregate stability to different disaggregation forces. Catena 53, 365-376.

Riley, K.L., Bendick, R., Hyde, K.D., Gabet, E.J. 2013. Frequency-magnitude distribution of debris flows compiled from global data, and comparison with post-fire debris flows in the western U.S. Geomorphology 191, 118-128.

Rubio, J.L. 1987. Desertificación en la Communidad Valenciana: antecedentes históricos y situación actual de la erosión. Revista Valenciana d'Estudis Autonòmicos 7, 231-258.

Rubio, J.L., Forteza, J., Andreu, V., Cerni, R. 1997. Soil profile characteristics influencing runoff and soil erosion after forest fire: a case study (Valencia, Spain). Soil Technology 11, 67-78.

Robichaud, P.R., Beyers, J.L., Neary, D.G. 2000. Evaluating the effectiveness of post-fire rehabilitation treatments. General Technical Report RMRS-GTR-63, U.S. Department of Agriculture, Forest Service, Rocky Mountain Research Station, Fort Collins, Colorado, USA.

Robichaud, P.R., Rhee, H., Lewis, S.A. 2014. A synthesis of post-fire Burned Area Reports from 1972 to 2009 for western US Forest Service lands: trends in wildfire characteristics and post-fire stabilisation treatments and expenditures. International Journal Wildland Fire 23, 929-944.

Sánchez, J., Mangas, V., Ortiz, C., Bellot, J. 1994. Forest fire effect on soil chemical properties and runoff. Soil erosion as a consequence of forest fires. Geoforma Ediciones, Logroño, pp. 53-65.

Sanroque, P., Rubio, J. 1982. El suelo y los incendios forestales. Diputación de Valencia, Valencia, pp. 57-63.

Seeger, M. 2007. Uncertainty of factors determining runoff and erosion processes as quantified by rainfall simulations. Catena 71, 56-67.

Shakesby, R. 2011. Post-wildfire soil erosion in the Mediterranean: review and future research directions. Earth-Science Review 105, 71-100.

Soler, M., Sala, M. 1990. La erosión producida tras un incendio en un encinar. In Actas de la $I^{a}$ Reunión Nacional de Geomorfología, M. Gutiérrez, J.L. Peña Monné, M.V. Lozano (Eds.), Instituto de Estudios Turolenses, Teruel, pp. 669-675.

Trabaud, L. 2002. Post-fire vegetation recovery and dynamics in the Mediterranean area. In Fire, Landscape and Biodiversity: an Appraisal of the Effects and Effectiveness, G. Pardini, J. Pinto (Eds.), Universitat de Girona, Diversitas, pp. 39-55.

Úbeda, X., Sala, M. 1998. Variations in runoff and erosion in three areas with different fire intensities. Geookodynamik 19, 179-188. 
Vega, J.A., Díaz-Fierros, F. 1987. Wildfire effects on soil erosion. Ecología Mediterránea 13 (4), 119-125.

Vega, J.A., Fernández, C., Fonturbel, T. 2015. Comparing the effectiveness of seeding and mulching + seeding in reducing soil erosion after a high severity fire in Galicia (NW Spain). Ecological Engineering 74, 206-212.

Villar Marcén, J. M. 2006. Biografía de un paisaje. Zuera. ISAC artes gráficas, Zaragoza, pp. 75-92.

Wagenbrenner, J.W., Macdonald, L.H., Rough, D. 2006. Effectiveness of three post-fire rehabilitation treatments in the Colorado Front Range. Hydrological Processes 20, 29893006. doi: 10.1002/HYP.6146.

Wischmeier, W.H., Smith, D.D. 1965. Predicting rainfall-erosion losses from cropland east of the Rocky Mountains. Agricultural Handbook 282, Agricultural Research Service, Department of Agriculture, United States of America. 